\title{
CHETTIAR CAPITAL AND THE EMERGENCE OF THE CHINESE BOURGEOIS IN BRITISH MALAYA
}

\author{
Ummadevi Suppiah ${ }^{1}$ and Sivachandralingam Sundara Raja ${ }^{2^{*}}$ \\ ${ }^{1}$ Department of Social Sciences, Teacher's Education Institute of Malay Women \\ Campus, Melaka, MALAYSIA \\ ${ }^{2}$ Department of History, Faculty of Arts \& Social Sciences, University of Malaya, \\ MALAYSIA \\ *Corresponding author: siva@um.edu.my \\ Published online: 15 April 2017 \\ To cite this article: Suppiah, U. and S. S. Raja. 2017. Chettiar capital and the emergence of the \\ Chinese bourgeois in British Malaya. Kajian Malaysia 35(1): 1-21. https:// \\ doi.org/10.21315/km2017.35.1.1 \\ To link to this article: https://doi.org/10.21315/km2017.35.1.1
}

\begin{abstract}
The historiography of Malaysia that addresses the Chinese and Indians rarely examines the interaction between the two ethnicities. In fact, works by Western and local scholars drew attention to the fact that the Chettiars operated outside ethnic parameters in Southeast Asia and particularly in Malaya. It has to be noted that the Chettiars were credit providers and financiers for the Chinese bourgeois from the early 19th century until the Second World War. This article explains how the Chettiars helped Chinese entrepreneurs in the economic development of British Malaya. Existing literature seems to depict the unbalanced view that the Chinese used their own capital and sought financial assistance from Chinese towkays and banks along with European commercial banks to develop their economic activities. The reality was that Chinese entrepreneurs also used the services of Chettiars as personal financiers and credit providers in crucial periods such as during the depression of the 1920 s and 1930s.
\end{abstract}

Keywords: Chettiar, capitalism/capital, Malaya, laissez-faire, Chinese bourgeois, business caste

\section{INTRODUCTION}

The Malayan colonial economy of the 19th and 20th centuries owed its development to the role played by the Indians, Chinese and Malays. All three ethnicities had significant roles in ensuring that the British reaped economic 
advantages in Malaya. In addition to the three ethnic communities was a classbased merchant group called the Chettiars. The Chettiar people were from South India and played the role of capitalists who contributed to the socio-economic needs of the three ethnicities and indirectly assisted the British in developing Malaya. Existing literature on the different roles of each of the three major ethnicities seems to focus on each ethnicity as a separate entity without exploring the economic bonds among them that contributed towards the development of the Malayan economy. The works referred to are Aiyer (1938), Sandhu (1977), Sinnappah (1979), Ampalavanar (1972), Palanisamy (1994), Purcell (1967), Chai (1964), Jackson (1968), Lee and Chow (1997), Khoo (1985), Jomo and Wong (2008) and others. There are also scholars who have given credit to a particular ethnicity for the development of the Malayan economy. For example, Isabella mentions "it is by their [Chinese] capital industry and enterprise that the resources of the Peninsula are being developed" (Bird, 2010: 31). Francis Light referred to the Chinese people in the Straits Settlements as "the only people of the East from whom a revenue may be raised without expense and extraordinary effort of government" (Andaya, 1982: 137). It is evident that the Chettiars' role is not highlighted in such literature. Existing writings on the relationship between Chettiars and the three ethnicities focus only on the mainstream groups of the Malay, Indian and Chinese communities without highlighting the role of the Chettiar community. For example, works by Mackenzie (1950), Yong (1987), Butcher (1979), Wu (2010), Cushman (1991) and Brown (1994) focus on the specific economic activities of the Chinese and only indirectly mention the role of the Chettiar as creditors. The latest work by William (2013) also mentions Chinese capitalism associated with Chettiar credit. Within this context, this article will draw attention to the role played by the Chettiars in providing loans to the Chinese who were engaged in all kinds of economic activities in Malaya.

Lack of banking facilities and the shortage of moneylenders among the Chinese led the Chinese to rely on Chettiar credit to develop their economic activities. In 1910, there were only two Chinese-owned banks in the Peninsula with small capital that favoured Chinese businessmen, while at the same time, the European exchange banks did not want to engage in long-term investment (Drabble, 1973: 69; Allen and Donnithorne, 1962: 203). According to Nanjundan, the Chettiars were the dominant moneylenders compared to the Sikhs and Chinese (Nanjundan, 1950: 17). This work, therefore, explains the economic relationship that existed between the Chettiars and the Chinese and how this relationship helped to strengthen the latter's contributions to the economic development of British Malaya. 


\section{CHETTIAR-CHINESE RELATIONSHIPS UNDER THE COLONIAL ECONOMY}

The presence of the Chettiar community could be traced to the reign of the first century South Indian kingdoms of India, namely those of the Cholas (100 to 1200 A.D.), Pandhya (200 to 1200 A.D.) and Vijayanagar (1300 to 1500 A.D.). Adas (1974: 393) opines that the Chettiars commenced their money lending activities in the 16th or 17th century during either the Portuguese era or the East India Company's rule in India. Their more recent history may be traced to the Western colonial era from the 14th to mid-20th centuries. With the arrival of Western trading powers, the Chettiars continued their coastal and international trading in South India, but only later under British colonial rule did the Chettiars focus their business on money lending. The Chettiars focused on money lending and banking activities in Madras Presidency because of their inability to compete with the Western trading powers and other Indian rivals along the Coromandel Coast. However, the British administration regulated Chettiar economic activities with more stringent laws to dominate trade investments in Madras Presidency (Mahadevan, 1978). In response, the Chettiars started to seek new business opportunities in the new British colonies in Southeast Asia including Malaya. They ventured into trading and money lending activities and established business relationships with the local people including the most dominant tradesmen-the Chinese of the Straits Settlements that later became the Malay States under the colonial economy.

From the beginning of the 19th century until the Second World War, the British laissez-faire policy in Malaya had a positive effect on the Chettiars' role as moneylenders and their relationship with the locals. The laissez-faire school of economic thought holds a pure or economically liberal market view: the free market is best left to its own devices, and it will dispense with inefficiencies in a more deliberate and timely manner than any legislating body. The basic idea is that less government interference in private economic decisions such as pricing, production, consumption and distribution of goods and services makes for a better and more efficient economy (Tylor, 1972). Under the British laissez-faire policy, European agents, British traders and Chinese and Indian merchants dominated the commodity trade in the Straits Settlements as investors and entrepreneurs until the rise of a commercial economy based on tin and rubber from the 1890s until 1942. In the free market, wealthy tradesmen were able to monopolise trade and make huge profits, while merchants and investors with little capital were forced to rely on trade agents, British exchange banks and moneylenders to obtain loans that allowed them to retain their foothold in open market trading. The British colonial administration allowed the South Indian indigenous banking caste (Chettiars) to play their part as moneylenders. Their liberal lending practices resulted in the Chinese (from towkays with big capital to rubber smallholders) to borrow from the Chettiars for their economic activities. 
The main economic activities of the Chinese in Malaya involved trading. Chinese trade activities took a leap when Penang, Malacca and Singapore came under the administration of the British East India Company (EIC). In Penang and Singapore, many of the Chinese were engaged in retail and wholesale businesses, carpentry, shipping, the opium trade, lease revenue, pepper, gambier and sugar cane cultivation. In Malacca, the Chinese were engaged in planting, manufacturing, trading and construction. From the early 1830 s, the Chinese were already involved in tin mining, as well as cultivation of gambier, pepper and cassava. Their involvement in commercial activities, mining and rubber cultivation only accelerated at the end of the 19th century (Drabble, 1983: 575). The Chinese who accumulated wealth from economic activities before the 1890s were major investors in mining and rubber cultivation. Early entrepreneurs among the Chinese took loans from other sources including the Chettiars to establish, develop and expand their businesses. The Chinese who borrowed money from the Chettiars were not only businessmen such as merchants, traders, wholesalers, lease holders, tin miners, planters and contractors; borrowers also included a non-commercial group of civil servants who sought assistance from the Chettiars. For instance, Khoo Choon Jin, a class II clerk, borrowed money from S. P. L. Pritchiappa Chetty (see NSS: 3409/1926, Civil Suit No. 426/26). However, this study found that the largest number of people who borrowed from the Chettiars were from the commercial group. These borrowers consisted of Chinese businessmen who had large- or medium-scale capital investments in privately run businesses or partnerships. Even so, the smallholder group was the largest group that borrowed from the Chettiars.

The following discussion will focus on how Chettiar credit assisted in the growth of the Chinese bourgeois in five key sectors - commodity trade in opium and rice, lease revenue, mining and rubber plantations.

\section{CHETTIARS AND THE CHINESE COMMODITY TRADERS}

Beginning in the 19th century, the Chettiars played an important role in the advancement of the Straits-born Chinese. Their commodity trading activities were concentrated in Singapore during its emergence as a major port in the Straits Settlements during the 19th century (Wong, 1960). From then on, the Chinese became active in commodity trading, including the import and export of opium and rice. The Chinese used profits from these trading activities to establish retail and wholesale businesses. This progress led to the development of urban infrastructure including the construction of retail shops. The expansion of trade and business activities contributed to the initial investments and the progress of the Chinese in other economic activities such as lease revenue, mining and rubber plantations. 
The rapid growth of Chinese commodity trading resulted in traders requiring significant sums of ongoing capital. Thus, Chettiars emerged as credit providers even before British commercial banks were established in the Straits Settlements. In the absence of banks, Chinese traders were dependent on the Chettiars for credit, hundi ${ }^{1}$ exchange and remittance. This role was performed through a network of Chettiar agencies linked to British commercial banks based in Rangoon and South India. Typically, Chinese traders would borrow money against the security of merchandise, ships or documents of promissory notes. The dealings between Chettiars and the Chinese merchants were used to good advantage by British commercial banks that began operations in the Straits Settlements in the 1840s. One of the branches of British commercial banks during this era was the Chartered Bank of India, Australia and China founded in Singapore in 1859 (Mackenzie, 1950: 105). The bank appointed Chettiars as agents to handle bank notes transactions involving the bank and Chinese merchants. This development also prompted Chettiars to play the role of credit providers as well as merchants.

\section{Chettiars and Chinese Opium Traders in Singapore}

Chettiars played a role in the opium trade in Singapore as a result of Singapore's role as a major base for the opium trade, the development of mining in Perak and Selangor and the emergence of British commercial bank branches in the Straits Settlements. The discussion in this section will focus on banks dependent on Chettiar agents in the business transaction of bank notes with opium traders and how this relationship further advanced the economic status of Chinese merchants in Singapore and other Malay states.

Although Chinese merchants made huge profits through the opium trade, they still relied on British commercial banks that financed massive imports of opium into Singapore. The role of banks actually helped the government to continue holding the monopoly over the opium trade in the Straits Settlements. The British banks depended on the services of Chettiars as exchange agents of bank notes between the banks and Chinese merchants involved in opium trading. In 1861, the Chartered bank was requested by the parent bank in India to issue bank notes because of the instability of the value and use of various types of silver currency (Mackenzie, 1950: 105). Bank notes used by British commercial banks in the Straits Settlements were paper currency backed by silver pound sterling. As bank agents, the main role of the Chettiars was to deal in bank notes according to the needs of traders, the current value of silver currency and the interest rate set by the bank. To engage in these business transactions, Chettiar agents had to deposit a sum of money in the bank to buy bank notes and then address the merchants. In this arrangement, the role of the Chettiars included transactions using bank notes, engaging in trading for the bank and borrowing money against the security of commodities. In the transaction of bank notes, 
Chettiars and merchants were more likely to exchange when the value of sterling silver currency or bank interest rates were low. The party who engaged in the transaction of bank notes had to have capital, trading expertise and knowledge of currency price speculation and interest rate calculation. The Chettiars exchanged their deposits in the bank with bank notes and then used the bank notes in trading opium with the Chinese. This situation is described by Mackenzie (1950) as follows: "Most of the Singapore opium trade passed through their [Chettiars] hands and they were careful to deal only with Chinese Merchants who were financially sound". Therefore, their role was not only limited to functioning as transaction agents but also as traders dealing in opium for the Chartered Bank. Direct trade relations with Chinese merchants and profits from the opium trade enabled Chettiars to give out loans to Chinese traders.

The Chettiars' role in assisting to develop opium trade in Singapore also helped advance other Chinese economic activities and infrastructure development in the Straits Settlements and in the Malay states. Profits from opium trade enabled many Chinese merchants to accumulate capital and invest in economic activities such as rice trade, mining, lease revenue, construction and wholesale and retail businesses. They were also the pioneers who used income from the opium trade to develop urban infrastructure including houses, shops, roads, settlements and other basic amenities.

\section{Chettiars and Chinese Rice Traders}

The Chinese bourgeois were also involved in the rice trade. Many Chinese merchants began to invest in the import of rice in the late 19th century to meet the needs of a growing population in the Federated Malay States (FMS). Although rice cultivation began in the district of Kerian (Perak), Merbok (Kedah) and Province Wellesley (Penang), their production could not meet the current demand (Hill, 2006: 56; 58; 84; regarding the rice shortage, refer to Kratoska, 1992: 282). Therefore, the British had to import rice from Java, Burma and Thailand with the help of Chinese merchants. The Chinese merchants in turn had to rely on credit assistance from the Chettiars to engage in rice trading and commerce in the Straits Settlements and Malay states.

One of the Chinese merchants who was successful in trading and importing rice at the end of the 1890s in Singapore was Tan Kee Peck, the father of Tan Kah Kee (Yong, 1987: 43). Kee Peck established Soon Ann, a rice firm during the 1870s that allowed him to accumulate capital and branch out into the real estate business (Yong, 1987: 21). Soon Ann dealt with rice imports from Cochinchina, Siam and Burma and sold rice to retailers in Singapore and the Malay States. According to Yong (1987: 22), one of the reasons for Soon Ann's economic success was Kee Peck's capable business and financial management. Unfortunately, the collapse of Soon Ann in 1904 was connected with Kee Peck's bad debts that amounted to $\$ 250,000$ through mortgages taken with Chettiars 
(Yong, 1987: 43). It was believed that the great increase in interest rates for money borrowed from the Chettiars was one of the factors that contributed to Kee Peck's indebtedness.

A large number of Chinese retailers also borrowed from Chettiars to conduct small-scale rice businesses in the Straits Settlements and Malay States. In 1872 for example, a retailer named Kang Oon Lock, trading under the brand name of Chop Teng Thye, had borrowed from Coomarapah Chetty to invest in rice trade in China Street, George Town (Straits Settlement, 1800-1884, 1885: 321). At that time, the consumption of rice as the staple food of Malaya enabled the Chinese to continue serving as middlemen in the rice trade with credit assistance from Chettiars. Evidence of this practice can be seen in the case of Lim Leng Cheak, who was the most important Chinese businessman engaged in domestic trade and import of rice into Penang and Kedah at the end of the 1890s. Through a network of established trade relations in Penang, Leng Cheak had many acquaintances among the Chettiars who provided credit for the expansion of his businesses mainly in revenue farming. Leng Cheak became actively involved in the leasing of paddy fields, milling and the export of rice to other Malay States and abroad. Leng Cheak even dealt in the sale of rice products from Kedah to Sumatra using his own ships. His success in the rice industry in Kedah resulted in the Sultan of Kedah awarding him monopoly over rice milling in 1888. Leng Cheak later formed a business partnership with a local dealer named Chong Chen Kean for the trading of rice branded as Chop Ban Heng Hee. At the end of the 19th century, the economic prosperity of Kedah was highly dependent on the outcome of rice trade conducted by Leng Cheak and his trading partners. Leng Cheak's business network provided adequate opportunities to wholesalers, retailers and rice millers in Kedah to expand their businesses and increase profits in the rice trade.

From the example above, it is clear that the early Chinese merchants received credit assistance from Chettiars to develop commodity trading of rice. Progress in commodity trading provided opportunities for Chinese businessmen to engage in wholesale and retail businesses in the Straits Settlements and other Malay States and to establish permanent settlements in the city.

\section{THE CHETTIAR'S ROLE IN AIDING CHINESE REVENUE FARMERS}

Chinese entrepreneurs also used financial resources from Chettiars as a liaison between the Chinese and the Malay rulers for the development of revenue farming and other economic activities. The British allowed these contacts and this kind of cooperation because lease revenue was the next major contributor towards national income after tin mining. The British earned substantial income from leasing activities through tax revenues and rentals of shop houses. For example, leasing activities contributed 33\% of FMS income from 1890 to 1894, 
which was almost equal to the export duty of $33.8 \%$ on tin in the same time period (Butcher, 1983: 388). This revenue was used to pay pensions and allowances to the sultans and to finance development projects such as the construction of railways. The success of Chinese entrepreneurs and the profits gained by the British and the Malay rulers through leasing activities were made possible through Chettiar credit assistance.

The Chettiars provided credit to lease revenue farmers who were willing to put up collateral in the form of landed property and imposed guarantees, as a large number of these borrowers were property owners and tin mining towkays. They normally borrowed large amounts, but profits were highly dependent on the success of the tin industry. This situation led Chettiar lenders to demand collateral of high value such as houses or mining land so that they would not suffer losses in the event that borrowers were unable to service the loans. Among the lease revenue farmers who borrowed from the Chettiars were Yap Ah Loy, Lim Leng Cheak, Khaw Soo Cheong (retail businessmen), Ng Boo Bee (a prominent distributor of brick and timber in Taiping) and Loke Yew. These terms of collateral-based lending resulted in the lease revenue farmers using profits from mining and leasing activities to buy landed properties that could be mortgaged when obtaining loans from Chettiar lenders (see Butcher, 1983: 398).

Chettiar lending conditions at the time were based on current global market conditions and the stability of the tin mining industry. The years 1907 and 1908 witnessed a sharp fall in the market prices of tin, affecting business activities and lease revenues (Butcher, 1983: 409). Therefore, the Chettiars were very cautious and reluctant to lend to the revenue farmers. This compelled the farmers to apply to the British government for a reduction in the lease rental rate, but they did not obtain a favourable response (Butcher, 1983: 409). On the contrary, the British used the concept of tender and gave opportunities only to Chinese businessmen who could afford to pay high rentals. This persuaded Chinese businessmen to continue borrowing from Chettiar lenders.

One such case involved $\mathrm{Ng}$ Boo Bee, who mortgaged his possessions to Chettiar lenders to settle outstanding debts for lease revenue business with the British (Butcher, 1983: 409). This was because Chettiar lenders were the only ones willing to provide loans to Chinese entrepreneurs to settle large debts with the British. British banks did not want to take the risk of lending to lease revenue farmers for fear that they could not repay their loans. Therefore, Chinese entrepreneurs desperately borrowed from Chettiar lenders who were willing to approve loans easily with higher interest rates than banks for loans with collateral.

This situation perpetuated the problem of indebtedness among Chinese entrepreneurs so much so that some of them submitted loan applications to the government to settle their debts. The British, however, rejected their applications as in the case of $\mathrm{Ng}$ Boo Bee (Butcher, 1983: 398). These developments 
prompted Chettiar lenders to act as surety to the lease revenue farmers to settle their loans.

\section{THE CHETTIAR'S ROLE IN AIDING CHINESE TIN MINERS}

One of the main commercial economic activities of the Chinese in Malaya in the 19th century was tin mining (Wong, 1965: 17-18). Chettiar moneylenders provided an important source of financing for Chinese tin miners (William, 2013: 87). The following discussion describes the recipients of Chettiar financial aid and how this aid helped the Chinese in the economic development of Malaya.

From 1850 until the 1920s, the Chinese were actively engaged in tin mining in Perak and Selangor. British policy encouraged the Chinese to get involved in mining and other economic activities. This was because four-fifths of the total income from Perak and Selangor came from economic activities carried out by the Chinese capitalists (Sadka, 1968: 332). Chinese entrepreneurial activities enabled them to accumulate sufficient capital for investment in tin mining. They had a tendency to invest in a number of economic activities at the same time. Mining operators were also major contributors in the business of capital lease revenue and rubber plantations. For example, most Chinese businessmen and major investors such as Loke Yew and Yap Ah Loy showed business acumen. However, the instability of tin prices on the global market greatly influenced profits. They required large capital to set up and manage new mining areas, recruit and manage labour, pay wages, provide facilities for the workers and settle debts. This was the main reason why many towkays had to borrow from the Chettiars. This can be observed through the statement made by a group of businessmen and clan business owners to the British Resident of Selangor, as follows:

That your humble petitioners have left their homes in China and have come to this state [Selangor] to carry out mining operations. That your humble petitioners have borrowed money from the Chetties, they do not deny but as the Chetties are pressing your petitioners before a material gain or profit is earned (Chinese Miscellaneous 2542/1897, 1897).

From this extracted quote, it is clear that Chinese businessmen who lacked capital relied on credit assistance from Chettiar lenders to continue involvement in mining activities. Some of the miners had already been in business but had not yet turned a profit, causing several towkays to make the following complaint during the 1890s: 
These Chetties in reality have no conscience. They keep constantly summoning and decreasing or decreeing against your petitioners mining property so much so that the tin trade is much retarded on account of their plaguing your petitioners in this manner and wishing to put of your petitioners who are respectable towkays in jail for debts there by disgraciously [sic] of our petitioner in the hope of recovering their money no matter where your petitioners are able to pay or not (Chinese Miscellaneous 2542/1897, 1897).

However, the British Adviser to Selangor favoured the Chettiars by stating that their decisive action against businessmen who refused to settle debts was not against state law.

Among the Chinese towkays who borrowed from Chettiar lenders was Yap Ah Loy, a great tin-mining entrepreneur who succeeded in obtaining mining concessions in Kuala Lumpur, Selangor and Negeri Sembilan. A clear record shows that K. V. A. L. Alagappa Chitty used lease letters of Yap Ah Loy for deposits worth $\$ 15,000$ to get a $\$ 2,000$ loan from the state government on 20 January 1892 (Selangor Miscellaneous 478/92A, 1892). Because of the collapse of tin prices that began in 1873 and the increased costs of investing in mining, Yap Ah Loy was heavily indebted to the government and British banks that were reluctant to extend him loans (Dally, 1969: 28; Middlebrook and Gullick, 1983: 45). This resulted in Yap Ah Loy having to seek alternative loans that were easily accessible through Chettiar moneylenders.

Credit assistance from the Chettiars helped Yap Ah Loy to repay debts to other creditors and sustain his role as the premier owner of leading mines in the state. This success prompted him to set up shops for the supply of essential goods and services to the miners and Chinese labourers. Through gains accrued from mining activities and lease revenues, Yap Ah Loy also developed permanent settlements for labourers in mining areas around Ampang and Pudu that eventually led to the development of Kuala Lumpur (Butcher, 1979: 11; Gullick, 1988). The success of Yap Ah Loy in the tin mining sector in the early stages was assisted by Chettiar credit, laying the foundation for success in his business expansion into other economic activities.

Another key figure in the Chinese tin mining industry who also had dealings with Chettiar lenders was Loke Yew who was known as the "Tin Magnate" and whose involvement in the tin mining industry started in Larut (Perak) in the 1870s. One of the factors for success was the concept of shared capital partnership among the Chinese, British and Indians, including the Chettiars and Thamboosamy Pillai (head of the Indian community in Kuala Lumpur). Loke Yew's good relations with Thamboosamy Pillai (Brown, 1994: 86) through shared capital for mining concessions in Selangor marked the beginning of his dealings with the Chettiars. 
Thamboosamy Pillai introduced a number of Chettiars in Selangor and Negeri Sembilan to Loke Yew to facilitate Yew's borrowing for capital investment purposes (Brown, 1994: 86). One of them was S. A. S. Chellapa Chetty, who was a member of the Selangor State Executive Council and the Kuala Lumpur Sanitary Board. Loke Yew's relationship with Chellapa Chetty deepened in 1904 when they both joined the committee on train carriage segregation with other Chinese towkays and Raja Bot (son of the Sultan of Selangor) to protest the segregation of railway passengers by which carriage A was reserved for Europeans and carriage B for other nationalities. Shared business capital and friendships with Chettiars not only motivated Loke Yew to open mining concessions but also to invest in other sectors such as railway management, rubber plantations and urbanisation.

In addition to Yap Ah Loy and Loke Yew, the Khaw family also created business empires assisted by loans from the Chettiars. The Khaw family was one of the big names in tin mining and business among the Chinese community in Malaya. Their business empire in the tin mining industry covered Malaya, Southern Thailand and Burma. Khaw Soo Cheong, the founder of the Khaw empire, invested substantial capital in the tin mining industry in Penang and Southern Thailand. He laid a solid foundation for his family business to engage in the tin industry on a larger scale. His son, Khaw Sim Bi, continued Cheong's efforts. Through a family-owned share investment company operating in Australia, Khaw Sim Bi established a tin smelting and tin dredging company in Malaya. This company, known as Eastern Shareholders, comprised speculators in world tin prices in Australia at the time. The Khaw family business escalated through the establishment of the Tongkah Harbour Tin Dredging Company in 1906 with an investment of $\$ 250,000$ through the Eastern Shareholders (Cushman, 1985: 5). Around 1907 and 1908, the Khaw family also set up another company called the Eastern Shipping Company that transported tin from Southern Thailand to Penang. The company operated in Penang with family capital investment of $\$ 1.5$ million in partnership with A. M. K. Raman Chetty, who contributed \$900,000 (Brown, 2000: 34).

The glory of the Khaw family business empire continued until the 1940s, maintained by the original business strategy of capital investment partnerships between the Khaw family, Australian investors and Chettiar firms. In fact, with the help of these financial sources and support from the Eastern Shareholders and Chettiar lenders, the Khaw family business empire was able to fully control the operations of two other tin mining companies, namely Tin Songkla NL and Shan Tin Dredging Limited (Brown, 1994: 183).

Apart from the large-scale Chinese entrepreneurs, there were also smallscale Chinese miners who benefited from financial relationships with the Chettiars. Normally, this group of Chinese miners mined areas leased to them by the Chettiars. This action prompted Chettiars to be directly involved in the mining industry and enabled tin miners with little capital to continue to 
participate directly in the tin mining industry, as they only had to pay the lease rental money to Chettiar mine owners.

Although the Chinese had financial resources from their families, partners, foreign and British financial institutions and Chinese banks, circumstances made them seek Chettiar financial help whenever needed. Most of the early Chinese entrepreneurs used their profits from the tin mining industry to invest in other economic sectors such as lease revenue, rubber plantations and urban development especially for the construction of shop houses.

\section{THE CHETTIARS' ROLE IN AIDING CHINESE RUBBER PLANTERS}

Chinese links with Chettiar lenders in the rubber industry started in 1872 when Tan Chay Yan, the first commercial rubber producer in Malaya, planted rubber in Malacca with credit assistance from the Chettiars (Muthupalaniappa, 2011: 154). The Chinese were the first Asian group to produce rubber in Malaya (Jackson, 1968: 221-222), followed by the Chettiar community. The relationship between the Chinese and the Chettiars in the rubber plantation sector was fostered through the sharing of capital and credit assistance. Chettiars loaned money to large as well as small-scale (smallholders) Chinese rubber producers who lacked capital. For smallholders, the loans were used to finance their living expenses during the recession. Further discussion will detail the circumstances that led small and large-scale Chinese producers to borrow from Chettiar lenders and the extent to which these loans benefited them.

Large-scale rubber producers borrowed from Chettiar lenders for investments in the rubber industry under varying circumstances. Among them were well known personalities such as Tan Chay Yan, Loke Yew, Tan Kah Kee and Tan Cheng Lock. Tan Chay Yan's reliance on Chettiar credit was due to the British policy on rubber cultivation and investment patterns at the time. He began rubber production on a commercial scale at the end of the 1890s on 40 acres of land interplanted with tapioca at Bukit Lintang, Malacca (Jackson, 1968: 218). In 1898, he established a Chinese syndicate called the Malacca Rubber and Tapioco Company to open up 1,200 acres of land at Bukit Asahan Estate near Gunung Ledang in northeastern Melaka for rubber plantation (Tan, 2008: 82) because of British policies that discouraged rubber cultivation on land already planted with other crops (Jackson, 1968: 218). This ruling caused Tan Chay Yan financial difficulties in meeting the high costs of planting rubber and the deterioration of trade in other commercial crops. The drop in prices of other crops also affected profits, and so Chay Yan's focus began to shift to the more profitable rubber sector.

Tan Cheng Lock ventured into the rubber industry without any basic knowledge in commercial agriculture because of his mother's insistence and capital assistance from a friend and his father-in-law. ${ }^{2}$ However, in 1921, Cheng 
Lock borrowed $\$ 10$ million from Chettiar lenders ${ }^{3}$ (Drabble, 2000: 57) to meet the increasing costs of rubber cultivation. Acquiring loans from Chettiar lenders had become easy thanks to his close relationship with a respected Chettiar personality in Malacca, O. A. R. Arunasalam Chettiar. In addition to managing his estate, Cheng Lock was also involved in land and rubber price speculation through the United Malacca Rubber Estates Limited, a company founded in 1910. A few other investors also borrowed money from Chettiars to carry out speculative investments through this company. The objective of the investors in the United Malacca Rubber Estates was to help Chinese rubber producers who had to sell their land to European investors because of their inability to compete with foreign investment in Malacca. Profits the company made were used to buy rubber plantations on a large scale. Even so, the gains were not enough, such that Chinese rubber producers sought to secure credit from external sources including retailers, miners and Chettiars. For example, in the early 1920s, Chettiar lenders in Malacca provided a loan of $\$ 10$ million to Chinese entrepreneurs securing rubber plantations as collateral (Drabble, 1973: 191).

Another well-known figure in the rubber industry, Tan Kah Kee, known as the "Rubber King" also made use of loans from Chettiar lenders (Brown, 2000: $35)$. He was well known in commercial pineapple and rubber production in Johore. In the early stages, Tan Kah Kee did not have enough private or family capital resources to invest in the rubber industry. Most of the time, he had to settle his father's debts to Chettiar lenders. This dealing created ties with Chettiar lenders through money borrowed by Tan Kah Kee to invest in the rubber industry. This task proved easy for Tan Kah Kee, so that by 1929, Tan Kah Kee owned 7,000 acres of rubber land located in Johor, Perak, Selangor and Singapore. Credit assistance from Chettiar lenders was also used for investments in the pineapple, rice and latex production industries and for business expansion into the South of Thailand (Brown, 2000: 35). According to Brown (1993: 271), Tan Kah Kee invested in Thailand through his two companies, namely Nam Thai and Tai Tong with loan assistance from Chettiar lenders in Penang.

Through these examples, it can be concluded that early large-scale planters among the prominent Chinese businessmen in the rubber industry borrowed from Chettiar lenders. There is no doubt that other big capitalists among the Chinese rubber producers also borrowed from Chettiar lenders to increase their rubber plantations. For example, Goh Tat Pang from Johor borrowed \$212,600 from S. N. Saminathan Chetty in 1911 (General Adviser Johore 1911-134/11), and Tan Hood Keng borrowed \$175,000 from A. R. P. Aroonaalam Chetty in 1909 (The Malayan Law Journal, 1934: 166).

Evidence also shows that some large-scale rubber producers relied on Chettiar credit because of British rejection of their loan applications. As an example, two wealthy Chinese rubber and cassava producers applied for shortterm loans totalling $\$ 400,000$ and $\$ 200,000$, respectively, from the Kedah government to cover production costs in 1920 (High Commissioner Office, 
Kedah 1983/1920, 1920). Because of very low commodity prices in the world markets, these producers did not want to sell their products, as that would have incurred great losses. At the same time, they were pressured by Chettiar lenders to repay their previous loans. In spite of the situation, the British were reluctant to approve loans to these businessmen, causing many large-scale Chinese entrepreneurs to borrow from Chettiar lenders for their survival.

Risks in the rubber industry caused many Chinese large and mediumscale entrepreneurs to share capital with the Chettiars to manage rubber plantations. In these partnerships, the Chettiars served as business partners and financiers. One of the Chinese who partnered with the Chettiars was Loke Yew. In 1902, Loke Yew, A. Guthrie and R. M. C. Alagappa Chettiar invested equally to purchase an estate in Kamunting, Perak (Brown, 1994: 41). Subsequently, in 1928, Letchumanan Chettiar together with Gan Kee and Ang Seng Kee requested a land area of 100 to 200 acres in Gemenceh, Negeri Sembilan to plant rubber (NSS 3167/1928). With the availability of Chettiar capital, Chinese large- and medium-scale entrepreneurs were able to invest in the rubber plantation sector.

In addition to the aforementioned loans, there were capital partnerships involving loans from other Chettiars. In 1933, for example, Ee Kong Guan and L. Kasivisvanathan Chettiar took loans from Muthuraman Chettiar to open a rubber estate known as Leong Hin Estate in Malacca (The Malayan Law Journal, 1934: 31). Their partnership lasted for five to six years and led to the opening of cooperative societies (limited company) for the purpose of rubber trade speculation.

\section{CHETTIAR AID TO RUBBER SMALLHOLDERS}

Chettiar aid also included more loans to Chinese smallholders compared to Malays. Until 1931, Chettiar lenders had given 75\% in total loans of $\$ 125$ million to Chinese smallholders in the FMS (Voon, 1987: 41). As of the mid-1930s, Chettiar lenders had extended $\$ 100$ million in loans to Chinese smallholders in the Malay States (Federal Council Proceedings, 1931: B16-23). The Chinese smallholders themselves acknowledged Chettiar contributions towards their economic development as follows:

(Petitioners) have had money raised from Chettiars and other moneylenders on the security of lands, in their enterprises of acquiring more lands or interested in business undertakings; (petitioners) have had dealings with the Chettiars and moneylenders for very many years and that they have been much benefitted in the time when the Rubber Market was at its normal stage (Selangor Secretariat Files 671/1933). 
Chinese smallholders' dependence on credit assistance from Chettiar lenders became more pronounced during the recession (periods of slump: 1920 22, 1929-32, refer to Drabble: 2000: 121). In addition to economic reasons, they used these loans to meet their basic, everyday needs. According to P. T. Bauer (1947: 75) [NSS No. 558/1947], a smallholder could manage five to six acres of rubber plantation on his own. However, they needed money to sustain themselves during the recession period. Poverty and strife were heightened when Chettiar lenders began to demand repayment of debts or forfeiture of mortgaged estates.

Chinese smallholders also borrowed in large amounts, and this increased if they owned a total area of over 50 acres. This category of smallholders preferred to increase acreage of rubber plantations more than that with less than 10 acres. Normally, they borrowed large amounts to purchase additional land for rubber plantations and for the high maintenance costs involved. According to P. T. Bauer (1947: 75) [NSS No. 558/1947], rubber smallholders who owned 50 to 80 acres of land employed contract labourers to work on their plantations. On average, from the period of recession until the Second World War, smallholders' debts with the Chettiars rose steadily. These smallholders did not invest in any other economic activities besides rubber cultivation as the large-scale Chinese entrepreneurs did. Lack of capital caused them to rely on earnings from rubber, and this was a factor that made them borrow money from Chettiar lenders for their daily needs. Loss of income and poverty led to defaults on repayments to their Chettiar lenders. Chettiar lenders acted decisively in the process of recovering loans. However, Chinese smallholders who were unable to repay their debts appealed to the Sultan or the British for assistance. For example, on 19 April 1933, a small number of Chinese smallholders from the outskirts of Selangor sent a petition to the Sultan of Selangor requesting help to save them from the clutches of Chettiar lenders. Excerpts of the petition are as follows:

1. (That your humble petitioners) have been harassed by the Chettiars and moneylenders demanding payment of the accrued interest on loans besides the principal sum and in default of payment a forced sales of property namely land.

2. (That your humble petitioners) beg to submit that most of the petitioners herein are men with children to support, nurse and to educate and all such requirements necessaries of life are to be met with within that humble inadequate income derived from the sale of the produce of their lands.

3. (That your humble petitioners) beg to submit that your petitioners are no way trying to evade payment but through lack of funds occasioned by the world-wide trade depression and to which no man can predict. 
From the above petition, it is clear that during the economic recession, the Chettiars were major providers of credit to Chinese smallholders in Selangor. This is evident because the writer of the petition neither named moneylenders other than Chettiar businesses nor denied having borrowed from other lenders. These petitions show the seriousness of the smallholders' indebtedness but at the same time demonstrate their sense of responsibility in wanting to settle their debts when the economy improved. This situation can be observed in the case of Chinese smallholders in Semenyih (Selangor) who continued to borrow from Chettiar lenders rather than from other financial sources until 1940 (Voon, 1978: 41).

The roles of the Chettiar as personal moneylender and credit provider were obvious in the rubber sector compared to other economic activities involving Chettiars and Chinese. This was because the rubber industry was the major economic domain of Chinese entrepreneurs after the 1930s, when European investors acquired the monopoly over mining. From this discussion, it is clear that Chinese rubber producers, whether large-, medium- or small-scale, borrowed from the Chettiars. The role of the Chettiar lender enabled large- and medium-scale Chinese planters to use their profits from the rubber industry to invest in other sectors of the economy compared to smallholders who were unable to do so because of their socio-economic conditions. However, the role of the Chettiar became very significant to smallholders, especially during the economic downturn, as Chettiar loans helped cover their daily domestic needs.

\section{CONCLUSION}

It is clear that Chettiars were instrumental in the economic development of the Chinese. It was common knowledge that Chinese capital contributed to the economic development of Malaya, as the British were unwilling to bear the costs of administrative and economic expenses from their intervention in the Malay states until the early 20th century. The economic development of Malaya was due to laissez-faire policies and the British expectation that local and foreign investors would boost the economy. Thus, the Chettiars exploited this situation by engaging in money lending activities to assist in Chinese economic development. The role of the Chettiars became more important when they provided loans to revenue farmers, tin miners and producers of gambier, pepper and rubber. All three of these economic activities contributed a great source of income to the British economy and to the Chinese in all three sectors, increasing production. It is also clear that many Chinese entrepreneurs, regardless of whether they had much or little capital, borrowed from the Chettiars. This finding proved that Chettiar capital helped Chinese businessmen to establish business empires and extensive business networks in and outside of Malaya, as well as to conduct large-scale businesses. It also showed that Chettiars had high 
entrepreneurial skill and had also become investment sources for other Chinese businessmen. Not only that, Chettiars also acted as sureties to the towkays in crucial moments to settle their debts to other lenders. The role of the Chettiar was more significant for smallholders until the mid-1930s, as the Chettiar loaned as much as $\$ 100$ million to the Chinese rubber smallholders in the Malay states. This article brings to the fore the bond that existed between the Chettiars and the Chinese in helping the British to develop the Malayan economy. It also rejects the theories and interpretations of some scholars who have given undue credit to Chinese enterprise as the sole factor responsible for the development of Malaya.

\section{ACKNOWLEDGEMENTS}

This study was funded by Hadiah Latihan Persekutuan - Biasiswa Penuh Melanjutkan Pengajian Peringkat Doktor Faksafah (August 2009-February 2013).

\section{NOTES}

1. Hundi is like the function of a cheque at present and an exchange of notes that can be used to send money and give credit. Hundi traded for the purpose of providing credit has to be changed in a period of one to four months (Rudner, 1994: 92-95).

2. At the insistence of his mother, Tan Cheng Lock helped his cousin Lee Chim Tuan, who was the owner of a rubber plantation in Bukit Rajang. His experience as a farm manager encouraged Cheng Lock to undertake his own rubber plantations in 1910. His effort was supported by his friend, his cousin and his wife, who provided the capital. His friend and his cousin lent him $\$ 10,000$, while his father-in-law invested $\$ 130,000$ for the industry. With this financial assistance, Cheng Lock bought Pinda Rubber Estates, Ayer Molek Rubber Company and the United Rubber Malacca Rubber Estates (Yeo, 1990: 9-10; Rose, 1990: 15).

3. Interview with Tan Sri G. Pasamanickam on 12th and 19th September 2010 at his office, Jalan Omri, Muar, Johore. He was an accountant at few money lending firms of Chettiar in Muar and Malaccca since 1930s. From 1950s until now, he involves in his own money lending activities in Muar. 


\section{REFERENCES}

Adas, M. 1974. Immigrant Asians and the economic impact of European imperialism: The role of the South Indian Chettiars in British Burma. Journal of Asian Studies 3(XXXIII): 385-401. https://doi.org/10.2307/ 2052938.

Aiyer, K. A. N. 1938. Indian problems in Malaya: A brief survey in relation to emigration. Kuala Lumpur: Indian Office, F.M.S.

Allen, G. C. and A. G. Donnithorne. 1962. Western enterprise in Indonesia and Malaya: A study in economic development. London: George Allen \& Unwin Ltd.

Ampalavanar, R. 1972. Class, caste and ethnicism among urban Indians in Malaya. Nusantara (2): 209-236.

Andaya, B. W. 1982. History of Malaysia. London: Macmillan Press Ltd. https://doi.org/10.1007/978-1-349-16927-6.

Bird, I. 2010. The golden chersonese. Singapore: Monsoon Books Pvt. Ltd. https://doi.org/10.1017/CBO9780511709913.

Brown, R. A. 2000. Chinese big business and the wealth of Asian nations. New York: Palgrave. . 1994. Capital and entrepreneurship in Southeast Asia. London: The Macmillan Press Ltd.

- 1993. Chettiar capital and Southeast Asian credit network in the interwar period. In Local suppliers of credit in the third world, 1750-1960, ed. G. Austin. New York: St. Martin's Press.

Butcher, J. G. 1983. The demise of the revenue farm system in the Federated Malay States. Modern Asian Studies 17(3): 387-412. https://doi.org/10.1017/S0026749X0000754X.

- 1979. The British in Malaya, 1880-1941. Kuala Lumpur: Oxford University Press.

Chai, H. C. 1964. The development of British Malaya: 1896-1909. Kuala Lumpur: Oxford University Press.

Chettiar, Muthupalaniappa. 2011. Malayaavin Thotram [The formation of Malaya]. Penang: Reprint.

Cushman, J. W. 1991. Family and state: The formation of a Sino-Thai tin mining dynasty 1797-1933. Singapore: Oxford University Press.

1985. Kinship and friendship: Economic ties among the Chinese business elite of Penang and Peninsular Siam. Paper presented at the Symposium Changing Identities of the Southeast Asian Chinese since WW II, The National University of Australia, Canberra, 14-16 June.

Dally, R. 1969. Yap Ah Loy-Capitan China. Singapore: Donald Moore Press Limited. 
Drabble, J. H. 2000. An economic history of Malaysia, C. 1800-1990: The transition to modern economic growth. London: Macmillan Press Limited.

1991. An economic history of Malaysia, c.1800-1990: The transition to modern economic growth. London: Macmillan Press Ltd.

. 1983. The Malacca rubber industry. In Melaka: The transformation of a Malay capital c.1400-1980, eds. K. S. Sandhu and P. Wheatley. Kuala Lumpur: Oxford University Press.

1973. Rubber in Malaya, 1876-1922: The genesis of the industry. London: Oxford University Press.

Gullick, J. M. 1988. Kuala Lumpur 1880-1895: A city in the making. Selangor: Pelanduk Publications (M) Sdn. Bhd.

Hill, R. D. 2006. Rice in Malaya - A study in historical geography. Singapore: NUS Press.

Jackson, J. C. 1968. Planters and speculators in Malaya: Chinese and Europeans enterprise in Malaya, 1786-1921. Kuala Lumpur: University of Malaya.

Jomo, K. S. and S. N. Wong. 2008. Law, institutions and Malayan economic development. Singapore: NUS Press.

Khoo, K. K. 1985. Sejarah masyarakat Melayu moden. Kuala Lumpur: Penerbit Universiti Malaya.

Kratoska, P. H. 1992. Rice cultivation and the ethnic division of labor in British Malaya. Comparative Studies in Society and History 24(2): 280-314. https://doi.org/10.1017/S0010417500009932.

Lee, K. H. and M. S. Chow. 1997. Biographical dictionary of the Chinese in Malaysia. Kuala Lumpur: Pelanduk Publications.

Mackenzie, C. 1950. Realms of silver: One hundred years of banking in the EastStandard Chartered Bank PLC. London: Routledge \& Kegan Paul Ltd.

Mahadevan, R. 1978. Pattern of enterprise of immigrant entrepreneurs: A study of chettiars in Malaya, 1880-1930. Economic and Political Weekly 13(4/5): 146-152.

Middlebrook, S. M. and J. M. Gullick. 1983. Yap Ah Loy, 1837-1885. Kuala Lumpur: Art Printing Works.

National Archives of Malaysia (NAM). 1885. Cases Heard and Determined in Her Majesty's Supreme Court of the Straits Settlements, 1808-1884. Vol. 1.

Federal Council Proceedings, 1931.

Chinese Miscellaneous.

Johore Branch: General Adviser Johore Files.

Kedah: High Commissioner Office.

- Negeri Sembilan: Secretariat (NSS) Files. 
NSS No. 558/1947 - P.T Bauer. 1947. Report on a Visit to the Rubber Growing Smallholdings of Malaya, July-September 1946. (Printed for Colonial Office).

- Selangor Land Offices - Mortgages, 8/9/1931-9/4/1932. Memorandum of charge, Schedule XXIV (a) - under section 129 of "The Land Code, $1926 "$.

Selangor Miscellaneous.

Selangor Secretariat Files.

Nanjundan, S. 1950. Indians in Malayan economy. New Delhi: Office of the Economic Adviser to the Government of India.

Palanisamy, R. 1994. Plantation labour, unions, capital, and the state in Peninsular Malaysia. Kuala Lumpur: Oxford University Press.

Purcell, V. 1967. The Chinese in Malaya. London: Oxford University Press.

Rose, A. S. 1990. Tun Dato Sir Cheng Lock Tan. Singapore: Alice Scott Rose.

Rudner, D. W. 1994. Caste and capitalism in colonial India: The Nattukottai Chettiars. California: University of Carfornia Press.

Sadka, E. 1968. Protected Malay States, 1874-1895. Kuala Lumpur: University of Malaya Press.

Sandhu, K. S. 1977. Indians in Malaya: Some aspects of their immigration and settlement 1786-1957. London: Cambridge University Press.

Sinnappah, A. 1979. Indians in Malaysia and Singapore. Kuala Lumpur: Oxford University Press.

Straits Settlement, 1800-1884. 1885. Coomarah Chetty versus Kang Oon Lock in Cases Heard and Determined in Her Majesty's Supreme Court of the Straits Settlements, 1808-1884, Vol. 1: 321.

Tan, P. L. 2008. Land to till: The Chinese in the agricultural economy of Malaysia. Kuala Lumpur: Centre for Malaysian Chinese Studies.

The Malayan Law Journal (III). July 1934. Edited by Bashir A. Mallal.

Tylor, A. J. 1972. Laissez-faire and state intervention in nineteenth-century Britain. London: Macmillan Press. https://doi.org/10.1007/978-1-34900661-8.

Voon, P. K. 1987. Indebtedness and land use in pre war Malaya, with special reference to the indigenous society. V. R. F Series No. 142. Kuala Lumpur: Institute of Developing Economies, University of Malaya.

William, T. Y. 2013. Chinese capitalism in colonial Malaya,1900-1941. Bangi: Penerbit Universiti Kebangsaan Malaysia.

Wong, L. K. 1965. The Malayan tin industry to 1914. Tuscon: The Association of Asian Studies by the University of Arizona Press. 
- 1960. The trade of Singapore 1819-1869. Journal of the Malaysian Branch of the Royal Asiatic Society (JMBRAS) 33(4): 1-315.

Wu, X. A. 2010. Chinese business in the making of a Malay state, 1882-1941, Kedah and Penang. Singapore: National University Press.

Yeo, S. S. 1990. Tan Cheng Lock: The straits legislator \& Chinese leader. Selangor: Pelanduk Publications.

Yong, C. F. 1987. Tan Kah Kee: The making of an overseas Chinese legend. Singapore: Oxford University Press. 